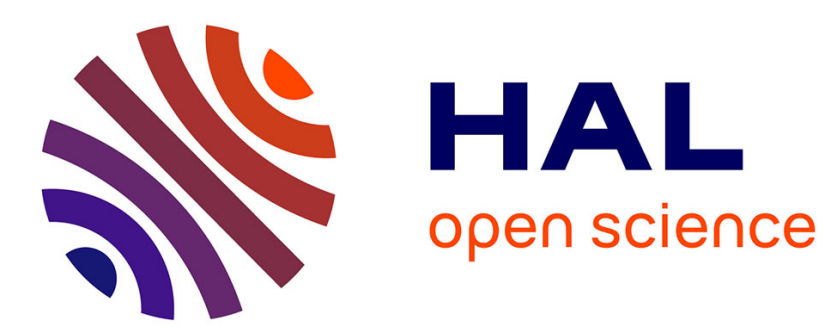

\title{
Preposition Stranding in Archaic and Medieval Chinese
}

\author{
Alain Peyraube, Lin Xiao
}

\section{To cite this version:}

Alain Peyraube, Lin Xiao. Preposition Stranding in Archaic and Medieval Chinese. A Life in Cognition - Studies in Cognitive Science in Honor of Csaba Pléh, 11, Springer International Publishing, pp.81-91, 2021, Language, Cognition, and Mind, 10.1007/978-3-030-66175-5_7 . hal-03506891

\section{HAL Id: hal-03506891 \\ https://hal.science/hal-03506891}

Submitted on 14 Jan 2022

HAL is a multi-disciplinary open access archive for the deposit and dissemination of scientific research documents, whether they are published or not. The documents may come from teaching and research institutions in France or abroad, or from public or private research centers.
L'archive ouverte pluridisciplinaire HAL, est destinée au dépôt et à la diffusion de documents scientifiques de niveau recherche, publiés ou non, émanant des établissements d'enseignement et de recherche français ou étrangers, des laboratoires publics ou privés. 
Language, Cognition, and Mind

Judit Gervain

Gergely essibra

Krítóf Kovács-yedizors:

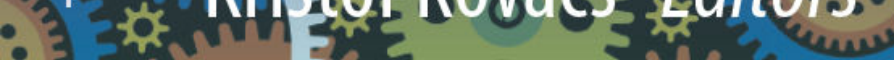

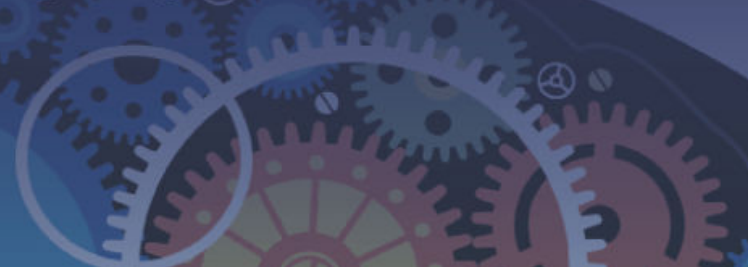


Judit Gervain · Gergely Csibra · Kristóf Kovács Editors

A Life in Cognition

Studies in Cognitive Science in Honor of Csaba Pléh

Springer 


\section{Editors}

Judit Gervain

CNRS

Paris, France

\section{Kristóf Kovács \\ ELTE Eotvos Lorand University \\ Budapest, Hungary}

\author{
Gergely Csibra \\ Central European University \\ Budapest, Hungary
}

ISSN 2364-4109

Language, Cognition, and Mind

ISBN 978-3-030-66174-8

https://doi.org/10.1007/978-3-030-66175-5
ISSN 2364-4117 (electronic)

ISBN 978-3-030-66175-5 (eBook)

(c) The Editor(s) (if applicable) and The Author(s), under exclusive license to Springer Nature

Switzerland AG 2022

This work is subject to copyright. All rights are solely and exclusively licensed by the Publisher, whether the whole or part of the material is concerned, specifically the rights of translation, reprinting, reuse of illustrations, recitation, broadcasting, reproduction on microfilms or in any other physical way, and transmission or information storage and retrieval, electronic adaptation, computer software, or by similar or dissimilar methodology now known or hereafter developed.

The use of general descriptive names, registered names, trademarks, service marks, etc. in this publication does not imply, even in the absence of a specific statement, that such names are exempt from the relevant protective laws and regulations and therefore free for general use.

The publisher, the authors and the editors are safe to assume that the advice and information in this book are believed to be true and accurate at the date of publication. Neither the publisher nor the authors or the editors give a warranty, expressed or implied, with respect to the material contained herein or for any errors or omissions that may have been made. The publisher remains neutral with regard to jurisdictional claims in published maps and institutional affiliations.

This Springer imprint is published by the registered company Springer Nature Switzerland AG The registered company address is: Gewerbestrasse 11, 6330 Cham, Switzerland 


\title{
Preposition Stranding in Archaic and Medieval Chinese
}

\author{
Alain Peyraube and Lin Xiao
}

\section{Abbreviations}

$\begin{array}{ll}\text { ASP } & \text { Aspectual marker } \\ \text { CL } & \text { Classifier } \\ \text { INT } & \text { Interrogative particle } \\ \text { NEG } & \text { Negation } \\ \text { NP } & \text { Noun phrase } \\ \text { OM } & \text { Object marker } \\ \text { FP } & \text { Final particle } \\ \text { PL } & \text { Plural marker } \\ \text { PP } & \text { Prepositional phrase } \\ \text { RM } & \text { Relative marker }\end{array}$

This modest contribution in honour of Csaba Pléh takes us back a decade or so when, on our initiative, the idea of organizing a strategic workshop on Nature and Culture at Lake Balaton was born within the European Science Foundation's Standing Committee for the Humanities. The success of this symposium later led Casba to join the Collegium de Lyon (CDL) to prepare the volume resulting from the Lake Balaton meeting (see Pléh et al. 2014). And it was during his stay in Lyon that we constantly discussed the interactions between linguistics and psychology, and in particular this phenomenon of preposition stranding, notably with Jim Blevins, who was also a fellow of the CDL at that time.

\footnotetext{
A. Peyraube

Centre National de la Recherche Scientifique et École des Hautes Études en Sciences Sociales, Paris, France
}

\section{Xiao $(\otimes)$}

École des Hautes Études en Sciences Sociales et École Pratique des Hautes Études, Paris, France 


\section{Introduction}

Preposition stranding (介词悬空 jiècí xuánkōng, sometimes called orphaned preposition) refers to a syntactic construction in which a preposition is left without a following object. If there is an object, it occurs somewhere other than immediately adjacent to its object. It is more often found in spoken language than in formal written language. This kind of construction is commonly found in English (where the preposition usually occurs at the end of the sentence), but also in other Germanic languages or dialects, and also in some languages belonging to the Niger-Congo family, but it is almost non-existent in Standard Mandarin, as has already been shown for a long time by Huang (1988). Well-known examples in various syntactic constructions English are:

(1) Who are you talking to? (Interrogative sentence)

(2) This is the guy I told you about (Relative clause)

(3) This new bed looks as if it has already been slept in (Passive structure).

This phenomenon is much rarer in the modern Romance languages (with the exception of Latin), but one can also find some examples in a register of widely spoken language, such as in French:

(4) Tu as vu cette fille récemment ? Oui, hier, j'ai encore dîné avec.

[Have you seen this girl recently? Yes, again yesterday I had dinner with].

Regarding the stranding preposition in Chinese, if we usually consider that there is none in standard Mandarin, we can however find stranded, hanging or dangling prepositions in contemporary various dialects. It is also assumed that preposition stranding was quite common in Archaic Chinese, and in Medieval Chinese as well, though in lesser proportions. However, no systematic analysis has been done yet on these former stages of the Chinese language, and especially for Early Medieval and Late Medieval Chinese.

We are momentarily trying to fill this gap in this short paper and to show that there has been the following typological evolution from Archaic to Medieval and later Modern Chinese: from [more preposition stranding] to [less preposition stranding].

\section{Archaic and Medieval Chinese}

Two common prepositions of Archaic Chinese are quite often subject of preposition stranding: 以 y̌̌ and 为 wèi. Other phenomena of preposition stranding are also attested in Medieval Chinese when the Classical Chinese prepositions 以 y̌ (pretransitive object marker, instrumental) and 于 yú (comitative, instrumental, locative, ablative, allative, dative, etc.) have become obsolete and have been replaced by other prepositions. See Liu (2017). 


\subsection{Archaic Chinese}

In Archaic Chinese, and more particularly in Late Archaic, which is also the Classical Chinese par excellence (fifth-second centuries BCE), we know since Wang (1962-1964) that the two most common prepositions 于 yú and 以 y̌̌ have opposite behaviors. See also Wang (1979), Peyraube (1988, 1994) and Djamouri (2009) for examples of $y \check{\text {, }}$, as far back in time as possible, i.e., in the Pre-archaic period (13th11th BCE). In the PPs with yú (yú + NP) the preposition yú can be deleted, while in PPs with $y \check{\imath}(y \check{\imath}+\mathrm{NP})$, it is the NP-object of $y \check{\imath}$ that is deleted, which constitutes a clear case of preposition stranding. This object of $y \check{\imath}$ is almost always the third personal or demonstrative pronoun 之 $z h \bar{\imath}$ 'it, this'. The other preposition that easily accepts preposition stranding is the 为 wèi 'for, to' preposition. Examples of preposition stranding with $y \check{\imath}$ are:

(5) 不敢以告人 (诗经. 国风. 唐 ca. $8^{\text {th }}$ BCE)

Bù găn yĭ gào rén (Shi jing. Guo feng. Tang)

NEG dare OM tell people

(I) dare not tell (it) (to other) people.

(6) 请以遗之 (左转. 隠元 $5^{\text {th }} \mathrm{BCE}$ )

Qǐng yǐ yí zhī (Zuo zhuan: Yin. yuan)

beg OM leave he

(I) beg (you) to leave (it) (to) him.

(7) ... 必以分人 (左传. 庄公 $105^{\text {th }} \mathrm{BCE}$ )

... bì yì fēn rén (Zuozhuan. Zhuang gong 10)

... certainly OM distribute people

... certainly distribute (it) (to) people.

In these last three examples, $y \check{\imath}$ is a direct object marker used especially in dative constructions (also called double-object constructions) which bring into play both a direct object and an indirect object. Cases of preposition stranding are very common when this preposition y̌ is introducing such a direct object marker. It is rarer, but not nonexistent, when the same preposition $y \check{\iota}$ is an instrumental preposition.

We also have interesting cases where the two objects of the dative construction, the direct object and the indirect object, are absent, which gives the form ' $y \check{\imath}+\mathrm{V}$ '. This occurs especially when the deleted objects are the third person pronoun $z h \bar{l}$, animated or inanimate:

(8) 子路行以告 (论语.微子 $5^{\text {th }} \mathrm{BCE}$ )

Zǐlù xíng yǐ gào (Lunyu. Wei zi)

Zilu leave OM tell

Zilu left and told (this) (to him) [Confucius]

Here, we have to understand 以告 y̌̌ gào as a reduced pattern of 以之告之 y̌̌ zhi gào zhi [OM it tell him] 'tell it to him'. 
Other examples with the comitative preposition 与 $y \check{u}$ 'with' are:

(9) 可与言而不与之言, 失人 (论语.卫灵公 $5^{\text {th }} \mathrm{BCE}$ )

Kě yǔ yán ér bù yǔ zhī yán, shī rén (Lunyu. Wei Ling gong) May with speak and NEG with he speak, err man

(When) a man may be spoken with, not to speak to him is to err in reference to the man.

In this last example, the object of the first preposition $y \check{u}$ 'with' is absent, while it is clearly expressed in the form of $z h \bar{l}$ behind the second preposition $y \check{u}$ 'with'. This represents a case of preposition stranding where the object of the preposition is absent but is expressed in a following context.

(10) 尝试与来 (庄子. 雍帝王 $4^{\text {th }} \mathrm{BCE}$ )

Chángshì yŭ lái

Have-a-try with come

Have a try to come with (him).

(11) 有争气者, 勿与辩也 (荀子.劝学 $3^{\text {th }} \mathrm{BCE}$ )

Yǒu zhēng qì zhě, wù yǔ biàn yě

There-is dispute anger the-one-who, NEG with argue FP

If there are people who want to quarrel and be angry, don't argue with (them).

It should be noted, at this stage, that this phenomenon of preposition stranding in Archaic Chinese concerns the written or the literary language, and not the more vernacular or even spoken language. This situation is the opposite of that which we will see in contemporary dialects.

\subsection{Medieval Chinese}

From the Han dynasty on (206 BCE) and during the whole period of Pre-Medieval (second century BCE-beginning of the third century $\mathrm{CE}$ ), the phenomenon of preposition stranding is still common. The prepositions of Classical Chinese which continue to be used are almost always followed by their object, but it is also true that some of these prepositions become obsolete and are replaced by new prepositions. This increases the number of cases that can be found, especially in Shi Ji (ca. 90 BCE) by Sima Qian (145-86 BCE) and in some Buddhist translations from the second century CE. The situation is approximately the same in Early Medieval period (3rd - 6th c. CE), but there are perhaps even more cases, especially in the Buddhist texts. Examples:

(12) 为具牛酒饭食 (诸少孙, 西门豹治业, $1^{\mathrm{st}} \mathrm{c}$. BCE)

Wèi jù niú jiŭ fàn shí (Zhu Shaosun, Ximen bao zhi ye)

for prepare beef wine meal food [example taken from Wang Li 1979]

Prepare beef, wine and food for (her). 
This example (12), dated Pre-Medieval, concerns the benefactive preposition wèi which has never disappeared and which is still used today in Standard Mandarin.

(13) ... 轧与俱 (世说新语. 赏誉 114 , first half of the $5^{\text {th }}$ c. CE)

... zhé yǔ jù (Shi shuo xin yu. Shang yu 114)

... always with altogether

(He was) always with (him) together.

This example is taken from the well-known New Account of the Tales of the World by Liu Yiqing (403-444) and involves the comitative preposition yŭ.

(14) 愿为市鞍马, 从此替爷征 (木兰诗, ca. $4^{\text {th }}$ or $5^{\text {th }} \mathrm{c} . \mathrm{CE}$ ) Yuàn wèi shì ān mă, cóng cǐ tì yé zhēng (Mulan shi) be-willing-to for buy saddle horse, from now instead-of father join-the-army (I) am willing for (it) to buy a saddle and a horse, (and) from now on to join the army in place of (my) father.

In this last example, which also dates from the Early Medieval period, it is the preposition wèi which is not followed by its object. As in previous examples cited above, it is undoubtedly the pronoun of the third person $z h \bar{\imath}$ which is deleted. The context indicates this time that the $z h \bar{\imath}$ refers here to an abstract noun: it = 'reason' I 'for this reason'.

Finally, we can consider that in Late Medieval Chinese (7th c. CE-1350), the phenomenon of preposition stranding has fallen practically into disuse. There is still, of course, some rare examples, but they obviously belong to a state of ancient language, such as the following one:

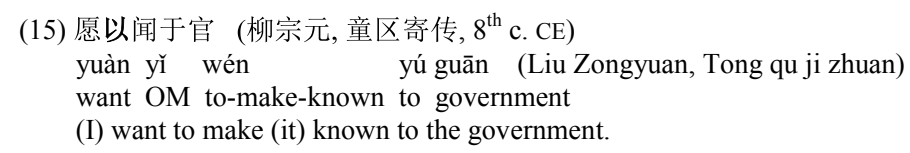

This last example of Late Medieval takes up the classic preposition y̌ which is the direct object marker in dative constructions. If it had not yet fallen completely into disuse at that time, it is probably because the pre-transitive direct object marker preposition 把 $b a ̆$, still used in Contemporary Chinese, had not yet fully imposed itself. Anyway, these rare examples of Late Medieval are pure Classical Chinese that date back to the Late Archaic era. They no longer represent the vernacular of the time at all.

And as was the case with Archaic Chinese, these rare examples of preposition stranding in no way reflect the vernacular of the time. 


\section{Contemporary Chinese}

\subsection{Standard Mandarin}

To say that there is never preposition stranding in standard Mandarin, as advocated by Huang (1988), Guo (2009) or Zhang (2009) deserves further discussion.

The absence of a prepositional object (shéi in [16], or $t \bar{a}$ in [17]) is of course impossible in the sentences corresponding to examples (1) and (4) above:

(16a) 你在跟谁说话?

$$
\begin{aligned}
& \text { Nĩ zài gēn shéi shuōhuà? } \\
& \text { you in-the-process-of with who speak } \\
& \text { To whom are you talking? }
\end{aligned}
$$

(16b) *你在跟说话?

*Nǐ zài gēn shuōhuà?

you in-the-process-of with speak

Who are you talking to?

(17a) 你最近见过这个女孩儿吗?

Nǐ zuijìn jiàn guò zhèi gè nŭháir ma?

you recently see ASP this CL girl INT

见过, 我昨儿还跟她吃饭了

Jiàn guò, wǒ zuór hái gēn tā chīfàn le

see ASP, I yesterday once-more with she eat PF

Have you seen this girl recently? Yes, again yesterday I had dinner with her.

(17b) 你最近见过这个女孩儿吗?

Nǐ zuìjìn jiàn guò zhèi gè nüháir ma?

you recently see ASP this CL girl INT

*见过, 我昨儿还跟吃饭了

*Jiàn guò , wǒ zuór hái gēn chīfàn le

see ASP, I yesterday once-more with eat PF

Have you seen this girl recently? Yes, again yesterday I had dinner with.

As for the examples (2) and (3) above, the entire PPs (the preposition and its following object) do not appear in the Chinese translations (18) and (19):

(18) 这是我跟你说过的那个家伙

Zhè shì wǒ gēn nǐ shuō guò de nà gè jiāhuǒ

this is I with you speak ASP RM that CL guy

Literal translation should be '*This is the guy I told you', and not 'This is the guy I told you about'. 
(19) 这个新床看起来好像有人已经睡过了

Zhèi gè xīn chuáng kànqǐlái hăoxiàng yǒu rén ỵ̌jīng shuì guò le this CL new bed look like there-is people already sleep ASP FP Literal translation should be '*This new bed looks as if it has already been slept' and not 'This new bed looks as if it has already been slept in'.

Regarding the passive structure (ex. 19), the absence of the preposition and its object is easily explained by the fact that the verb shui 'to sleep' in Chinese can also be transitive and does not need a preposition to introduce its object, especially when the NP-object in question is followed by a localizer. "Sleep in bed" can be both translated by 睡床上 shuì chuáng shàng [sleep bed on], as well as 睡在床上 shuì zài chuáng shàng [sleep at bed on]. As for the relative clause (ex. 18), things are more complicated, but they depend on the strategy of the formation of relatives in Chinese. See Zhu (1983).

There are also cases where one might think that we are dealing with a phenomenon of preposition stranding when prepositions like 用 yòng 'with' or even 给 gěi 'to' are used, for example in:

(20) 这把刀我用来切菜

Zhèi bă dāo wǒ yòng lái qiē cài (ex. taken from Guo Rui 2009)

this CL knife I with/use in-order-to cut vegetable

I cut vegetables with this knife.

I use this knife to cut vegetables.

(21) 这把刀我切菜用, 那把刀我切肉用

Zhèi bǎ dāo wǒ qiē cài yòng, nèi bă dāo wǒ qiē ròu yòng this CL knife I cut vegetable with/use, that CL knife I cut meat with/use I cut vegetables with this knife, and I cut meat with that knife.

(22) 他给修不给? (= 他给你修不给?)

Tā gěi xiū bù gèi? (= Tā gěi nǐ xiū bù gěi ?)

he for/let fix NEG to/let (= he to/let you fix NEG to/let)

*Did he fix (it) for? (= Did he fix (it) for you?)

Did he let fix it? (= Did he let you fix (it)?

However, it is undoubtedly preferable, as Guo (2009) suggests, that we are not dealing then with simple sentences with a PP and a single verb, but with serial verb constructions where two verbs (V1 and V2) coexist in the same sentence. In other words, in these examples yòng should be considered as a verb 'to use, to employ' and not as a preposition 'with', and gěi as a causative verb 'let' instead of a dative or benefactive preposition 'to, for'. In fact, the grammaticalization process of the verb yòng into a preposition is probably not completely achieved, as is the case for other prepositions which are also derived from verbs. And it is well-known that the verb gě $i$ has been poly-grammaticalized into a causative verb and a dative preposition (See Chappell \& Peyraube, 2011). The examples above are thus a phenomenon of verb stranding, which is indeed cross-linguistically much more common than preposition stranding. 


\subsection{Other Sinitic Languages}

There is no doubt, however, that we indeed have preposition stranding in several Chinese dialects (or Sinitic languages). Cases have been regularly reported over the last years in dialects in the provinces of Anhui (by Hu, 2006), Hunan (Ding, 2009), Shaanxi (Zhang, 2013), but they are far from being entirely convincing, as it is always difficult to know if we are really dealing with prepositions, and not verbs, which is the eternal question in an analytical language like Chinese.

However, Zong's study (2019) on the preposition stranding in the Zhangjiakou dialect (Hebei province) shows that the preposition stranding at least with the preposition 跟 $g \bar{e} n$ is undoubtedly common. Thus, in the following example (23), it is not possible to hesitate long to know whether $g \bar{e} n$ is a preposition or a verb. It goes without saying that this $g \bar{e} n$ should be considered as a preposition. It cannot be the verb 'follow'. But for this sentence to be possible, says the author, the context must indicate somewhere that the two interlocutors are used to eating together every day.

(23) 你今儿不跟吃饭了? (= 你今儿不跟我吃饭了?)

Nĩ jīnr bù gēn chīfàn le? (= Nĩ jīnr bù gēn wǒ chīfàn le?)

You today NEG with eat FP (= You today NEG with I eat FP)

You don't eat with (me) today?

The same is true in the following example (24). The two interlocutors are used to harmonizing the strings of their instruments together.

(24) 那以后, 一到下午她就主动找我要跟调弦

Nà yǐhòu, yīdào xiàwǔ tā jiù zhǔdòng zhăo wǒ yào gēn
so after, as-soon-as afternoon she then take-initiative look-for I want with
tiáo xián
harmonize string (of an instrument)

So, after (that), as soon as the afternoon (arrived), she took the initiative to look for me, (and she) wanted to harmonize the strings with (me).

These cases of preposition stranding are especially common when the object of prepositions, which is absent, appears in a previous context, especially when it has been topicalized. Examples:

(25) 你尽量跟叔叔们说说...我说我跟说说

$\mathrm{Nĩ} \mathrm{jìnliàng} \mathrm{gēn} \mathrm{shūshu} \mathrm{men} \mathrm{shuōshuo} \mathrm{...}$
You as-much-as-possible with uncle PL talk-about-a-little
$\ldots$ wǒ shuō wǒ gēn shuōshuo
.. I say I with talk-about-a-little
You talk a little with (your) uncles as much as possible ... I said I will speak with
(them).

Other prepositions than the $g \bar{e} n$ preposition are also subject to the stranding preposition in this Zhangjiakou dialect, in particular the preposition bă (direct pre-verbal object marker), the other comitative preposition hé 'with', the ablative preposition cóng 'from', etc. Examples: 


\section{(26) 写了两封信, 把寄走了}

Xiě le liăng fēng xìn, bă jìzǒu le write ASP two CL letter, OM send ASP

(I) have written two letters, (and) I mailed (them) out.

The objet marker bă (a preposition) is not followed by any object, but the item to which this preposition refers ('two letters') is mentioned in the first part of the sentence.

(27) 爸爸去北京, 小李也和去了

Bàba qù Běijīng, Xiăo Lǐ yě hé qù le

Dad go Peking, Xiao Li also with go ASP

Dad went to Peking, Xiao Li also with (him).

The comitative preposition hé is not followed by any object, but the item to which this preposition refers ('Dad') is also mentioned in the first part of the sentence.

(28) 他不在饭馆儿了, 早从出来了

Tā bù zài fànguănr le, zăo cóng chūlái le

he NEG be-at restaurant ASP, early from leave ASP

$\mathrm{He}$ is not in the restaurant, he left (it) early.

The ablative preposition cóng is not followed by any object, but the item to which this preposition refers ('restaurant') is also mentioned in the first part of the sentence.

These examples in the Zhangjiakou dialect are not possible in Standard Mandarin. Of course, there are still conditions which limit the use of these preposition stranding phenomena in Zhangjiakou. All prepositions, first, do not tolerate preposition stranding. Zong (2019) also judiciously noted that it is easier for prepositions not to be followed by their object when the language style is deliberately spoken and even with a popular register. It also seems that in most cases, this object is a pronoun. When it is an NP, it cannot be an abstract name, it is always a noun referring to a concrete content, like 'letters' or 'restaurant' in the examples above.

The other conditions which he suggested are however questionable, for example the greater ease for dissyllabic prepositions to be subjected to preposition stranding compared to monosyllabic ones or the difficulty for prepositions which are the most grammaticalized to be able to delete their object. If this is certainly the case of yòng, as we have seen, we can doubt that the prepositions gēn, bă, hé or cóng in the examples above remain weakly grammaticalized, especially for the preposition cóng.

One thing remains certain. This phenomenon of preposition stranding in Zhangjiakou or other Sinitic languages is reserved for a register of widely spoken language, in contrast to the same phenomenon in Classical Chinese or in Medieval Chinese.

\section{Discussion, Conclusion, and Further Investigations}

There was undoubtedly a preposition stranding in Archaic Chinese (i.e., Classical Chinese) which was relatively common. The phenomenon then became more 
common in the Pre-Medieval and Early Medieval periods, and as the language evolved, it practically disappeared during the Late Medieval period.

It no longer exists today, or very marginally in Standard Mandarin, but it is singularly present in different dialects which are not spoken in the same geographical area and therefore cannot constitute a linguistic area. How then to account for this existence of preposition stranding in such different dialects?

The easiest hypothesis which consists in saying that it is a borrowing phenomenon seems to us far-fetched. No reliable source of borrowing can be found. In the absence of a possible borrowing through language contact, there remains the hypothesis of an internal change, or rather of the maintenance of a structure which existed long time ago in Archaic Chinese and which has disappeared later in almost all the other Sinitic languages.

To confirm this hypothesis, however, it would be necessary to know whether this preposition stranding has always existed in this dialect of Zhangjiakou, where it seems to be the most common, or whether it is a recent phenomenon that dates back only several decades, or even one or at most two centuries. If this were the case, we would not be dealing with the preservation of a structure, but with a typical case of exaptation (i.e., giving a new existence with different characteristics to an old form which has fallen into disuse or has even completely disappeared; see Peyraube, 2014). This would also make it possible to better account for the fact that we have moved from a phenomenon of preposition stranding reserved for the literary language to a similar phenomenon but attested only in a spoken language register.

Whatever the case may be, the preliminary diachronic study undertaken in this article (it is only a general overview) certainly deserves to be deepened, especially for the period of the Late Medieval (7th c. CE-1350), and, above all, for the following period (Modern Chinese) which extends from the middle of the fourteenth century to the eighteenth century, date on which begins the stage of Contemporary Chinese.

If we are dealing with a phenomenon of exaptation, it may indeed be that in Modern Chinese the preposition stranding existed more than in the previous stages, which could suggest that some Contemporary Chinese dialects have kept these forms. But this is a hypothesis which also remains highly debatable and which will undoubtedly be very difficult to justify, given that the materials which are supposed to truly reflect the spoken language in ancient times are very often questionable, not to mention the extreme difficulty of identifying them with precision from a typological and dialectological point of view.

It could also be that the two cases of preposition stranding (in Classical up to Medieval Chinese and in contemporary dialects) have no relation to each other. It would simply be a semantic-pragmatic development of its own linked to the ellipsis phenomena often very common in Chinese discourse. One would then have the right to wonder whether this phenomenon could become generalized in other Sinitic languages, and especially including standard Mandarin.

All these hypotheses deserve to be explored further. 


\section{References}

Chappell, H., \& Peyraube, A. (2011). Grammaticalization in Sinitic languages. In H. Narrog \& B. Heine (eds.), The Oxford handbook of grammaticalization (pp. 786-796). Oxford University Press.

Ding, J. (2009). Longhui xiangyu de 'N+dan+VP' chuzhishi (Disposal structure 'N+dan+VP' in Xiang language of Longhui). Hапуи хиеbao (Chinese), 4, 42-46 + 95-96.

Djamouri, R. (2009). Cong jiagu, jinwen, kan 'yi' zi yufahua de guocheng (The grammaticalization of 'yi' in oracle and bone inscription). Zhongguo Yuwen (Chinese Language), 1, 3-9.

Guo, R. (2009). Xiandai hanyu he gudai hanyu zhong de jieci xuankong he jieci shanchu (Preposition stranding and deletion in Mandarin and Classic Chinese). Zhongguo Yuyanxue (Chinese Linguistics), 2, 23-36.

Hu, D. (2006). Anhui wuhu qingshuihua zhong de 'wu binyu baziju' (On the 'ba' construction without object in the Qingshui dialect of Wuhu in Anhui province). Zhongguo Yuwen (Chinese Language), 4, 342-345.

Huang, Z. (James Huang, C. -T.), (1988). Hanyu zhengfan wenju de mozu yufa (A modular grammar of A-not-A questions in Chinese). Zhongguo Yuwen (Chinese Language), 4, 247-264.

Liu, D. (2017). Yufa diaocha yanjiu shouce (Handbook of grammatical fieldwork). Di'er (2nd ed.). Shanghai Jiaoyu Chubanshe.

Peyraube, A. (1988). Syntaxe diachronique du chinois-Evolution des constructions datives du 14ème siècle avant J.-C. au 18ème siècle. Collège de France.

Peyraube, A. (1994). On the history of Chinese locative prepositions. Zhongguo Jingnei Yuyan Ji Yuyanxue (Chinese Languages and Linguistics), 2, 361-387.

Peyraube, A. (2014). Syntactico-semantic change in Chinese: Processes of analogy, reanalysis, external borrowing. In G. Peng \& F. Wang (Eds.). New horizons in evolutionary linguistics (pp. 181-221). Journal of Chinese Linguistics Series 27.

Pléh, C., Csibra, G., \& Richerson, P. (Eds.) (2014). Naturalistic Approaches to Culture. Budapest: Akadémiai Kiadó.

Wang, L. (1962-1964). Gudai hanyu (Ancient Chinese (Vol. 4)). Zhonghua Shuju.

Wang, L. (1979). Gudai hanyu changshi (Elementary knowledge of ancient Chinese). Renmin Jiaoyu Chubanshe.

Zhang, Y. (2009). Jieci xuankong de fangshi he houguo, dongyin he zuoyong (On the patterns and results, causes and functions of Chinese preposition stranding). Yuyan Kexue (Language Sciences), 3, 288-303.

Zhang, Q. (2013). Shanxian fangyan de jizhong jieci yufa xianxiang (Some grammatical issues in prepositions in Shanxian dialects). In Liu D. (Ed.), Hanyu fangyan yufa yanjiu de xin shijiao (New perspectives of grammatical studies of Chinese dialects). Shanghai Jiaoyu Chubanshe.

Zhu, D. (1983). Zizhi he zhuanzhi-hanyu mingcihua biaoji 'de, zhe, suo, zhi' de yufa gongneng he yuyi gongneng (Self-designation and transferred-designation: A study on the syntactic and semantic functions of the nominalizing particles 'de, zhe, suo and zhi'). Fangyan (Dialects), 1, $16-31$.

Zong, S. (2019). Jieci xuankong: Zhangjiakou fangyan de xianhe jufa jiegou (Preposition stranding as a prominent syntactic structure in the Zhangjiakou dialect). Zhongguo Yuwen (Chinese Language), 5, 532-543. 